\title{
At the nexus of vulnerability: Multilingualism in development
}

\author{
Kenneth Hyltenstam \\ Stockholm University
}

\section{Christopher Stroud \\ University of the Western Cape and Stockholm University}

\begin{abstract}
A note on the background to this paper
This document was written in the early years of this century, about 15 years ago. It emerged out of more than a decade's engagement in matters of multilingualism, language, politics and education in Mozambique specifically, and Southern Africa more generally, that we had been involved in through the Centre for Research on Bilingualism at Stockholm University. The document itself was written at the request of SIDA, the Swedish International Development Cooperation Agency, and its research wing, SAREC, that had funded the majority of projects in language and education up until that point. The idea was to craft the outlines in a working document of a more comprehensive and sustained policy, or action plan, on issues of language in developing contexts. This was at a time of a growing awareness in the organization that its key funding areas - democracy, poverty, education, youth - involved language in much more complex ways than hitherto envisaged, and that a specialist document written for the layman might enlighten and provide direction.
\end{abstract}

Our concern as authors was to bring out how language comprised the very nexus of vulnerability in developing contexts. Whereas health, economy, education, democracy etc have always been institutionally well-defined silos with cadres of specialists (economists, educators, political scientists etc) in development projects, issues of language have received scant specialist attention, and then almost only within educational programs. In this context, much attention has been paid to addressing the lack of trained teachers, the development of adequate teaching materials and classroom practices, with less worry about how such strategic assistance had often reproduced existing and historic al inequities rather than alleviate them. Kenneth Hyltenstam and I had earlier argued that questions of educational delivery needed to look beyond bricks and mortar, text books and desks in order to also focus on subtleties and complexities of workings of language that could not easily be dealt with in unit and audit terms. The purpose of this short text was to extend this argument, and lift forward the centrality of language across all development arenas.

Clearly, there was much that could not be said in a text of this type, partly due to the constraints on format, readership and purpose, but also because conceiving of language as a nexus of vulnerability requires a radical rethinking of a concept of 
language relevant to the everyday business of being human, of managing diversity and encounters across difference in respectful and ethically appropriate ways. The philosopher Gadamer in 'Truth and Meaning' has noted how "language is often thought of as a secondary dimension in the happening of the world... rather than something emerging out of the embodied mode of our being in the world" (Malpas, ms p. 11). Rather more modestly, I have suggested that some idea of linguistic citizenship might offer an approach to fronting questions of how language and linguistic marginalization are integral to, and co-original with, socio-economic and political marginalisation. The notion of linguistic citizenship emerged out of the felt need for a perspective that situated linguistic practices and representations of speakers firmly within their everyday sociopolitical strivings for agency and transformation. It built on Nancy Fraser's (1995) notion of bivalent collectivity that refers to groups where neither socio-economic maldistribution or cultural misrecognition are an indirect effect of the other, but where both are primary and co-original.

The reference list in the report is dated and sparse, and much has happened in the area of language, development and citizenship, since this short paper was written. However, not much has happened in one important respect, and that is in developing a more adequate understanding of the potential in a rethought idea of language for managing vulnerability.

\section{Christopher Stroud}

September 2016

\section{INTRODUCTION}

$\mathrm{T}$ he majority of the world's nations are multilingual, although many of the languages spoken have little or no official recognition in the conduct of everyday affairs of State, nor do they figure in any major way in development discourses. For example, although UNESCO and other World and regional organizations frequently underscore the desirability and importance of multilingualism, it is often in the context of education and cultural heritage rather than development more generally. Lack of recognition, however, does not mean that multilingualism does not play an essential role in the public and private lives of citizens. In this short text, we hope to drive home the point that local linguistic resources also directly bear upon democracy, economy, and health. And this is not just by proxy through the known beneficial effects of educating in local languages. We will suggest that more attention be paid to the various ways in which development can benefit from the use of local multilingualisms.

Language is important in development precisely because it is at the nexus of vulnerability. Poverty stricken groups in developing contexts are not only the least resourced. They

- are also the least visible

- lack political and cultural recognition on official arenas

- frequently suffer stigma and ambivalence with respect to their cultural heritage

- have a paucity of educational capital

- experience poor health.

One major factor contributing to this cycle of vulnerability - and for which solutions are within easy reach - is that the linguistic and cultural systems these 
groups have ready access to are not officially recognized. Non-recognition of the languages in which groups organize their everyday life and socialize their children means that they are denied the tools to make their voices heard or to find empowerment through political agency. They also have few opportunities to influence their day-to-day material conditions. The ultimate consequence of this situation is extreme vulnerability to political, economic and ecological (including health) developments.

In this document, we shall argue, by way of illustration, that issues of language in general and multilingualism specifically need to be seen as core facets of such diverse areas as democracy, economy, health, and education. Each of these areas will be treated in a separate section, and where possible, the discussion will also make reference to the way in which consideration of multilingual practices is also highly pertinent to issues of gender equity. Our focus will be on the role that language and multilingualism play at the level of formal politics and organization, as well on the informal arenas where the everyday realities of poverty and its ramifications are linguistically managed. A key concern will be to suggest ways in which the everyday 'linguistic politics of informality' may articulate with formal political spaces, something that is essential for the true participation of the poor in development and poverty alleviation. One focus in the text will therefore be on the role of informal networks of activities in development.

Before we enter on the main discussion, we will first discuss briefly the notion of multilingualism to be followed by a short explication of how we take the idea of development.

\section{MULTILINGUALISM}

In general, at the level of society, multilingualism is often conceived of in terms of a multiplicity of territorially delimited language labels. So, for example, in the case of Mozambique, it is generally characterized as a multilingual territory comprising 21 different languages, among which we find Emakua spoken by $40 \%$ of the population and Portuguese spoken by a mere $2 \%$. At this level, languages are organized in terms of size, geographical distribution, and, most importantly, in terms of their status as official, national, regional, local, (or other) languages. Official languages are associated with the public or formal sphere, and are therefore languages of power. Their status as languages of power is mirrored in the amount of resources that are invested in them (for example, in terms of materials translated into them, in terms of capital transference, that is, how many speakers of other languages make an investment to learn them, the number of man-hours that are dedicated to cultivating and developing the language (orthography, dictionary and grammar). However, the privileged and powerful position these languages are granted is also because they are often the (preferred) language of the elites. In many cases, official languages of the State administration are non-indigenous, metropolitan languages that are not spoken natively by the local population.

At the individual and group level, multilingual resources are organized in such a way that speakers are assigned to languages as mother-tongue (or native speakers) or as second/foreign language speakers. Traditionally, the status of mother tongue confers ownership and historicity to speakers of these languages - if you speak a language as a mother tongue, this means that you have 
inherited the language from your family, acquired it in everyday socialization and therefore are linked closely with this language as part of your autobiography. Mother tongues therefore become per fiat associated with authentic identities and everyday local relevance (cf. Stroud, 2002).

This way of viewing societal and individual multilingualism however, is just one possible construction. It is a construction that assumes the existence of distinct languages that can be technically delimited, and the unproblematic assignment of speakers to these languages. In reality, the situation is far more complex. Speakers often master multiple languages and multiple varieties of them, and these languages frequently co-occur in everyday speech in hybrid and syncretic utterances that cross-cut language boundaries. Further, speakers will not always use metropolitan languages to talk about official business, or local languages to talk about affairs of home and hearth, which means a lack of fit between societal function and language type.

It is also frequently the case that speakers may have more than one mother tongue, and that they consider themselves to be proficient speakers of a metropolitan language. In fact, the first learnt language may not be the language a speaker identifies most closely with or is most proficient in. On the other hand, a second language may be considered to be of greatest everyday relevance to a speaker. It follows that notions such as identity, authenticity, and relevance will not bear any one-to-one relationship with any single language.

Therefore, in our general discussion below, we propose to talk about language in ways that highlight the importance of attending to the multilingual practices of speakers and fluidity between linguistic boundaries. In summary, to look closely at what people do with language rather than what linguistic labels they profess allegiance to.

\section{DEVELOPMENT}

We take development here to mean freedom from vulnerability to social dynamics beyond one's control (cf. Markee, 2002). In particular, this involves freedom from poverty, which is the most pernicious type of vulnerability. One goal of development is therefore to increase individuals' control over processes of economic development (cf. Bruthiaux, 2002). Going beyond economics and poverty reduction, the economist Amartya Sen, who received the 1998 Nobel prize "for analyzing the causes of famine and other welfare economics issues", has argued for an understanding of development more generally as freedom, claiming that this is both the goal of, and the means for, development (Sen, 1999). Sen is thereby propounding a view of development as fundamentally a process that requires the democratic participation and agency of those that are disadvantaged.

The Swedish Ministry of Foreign Affairs has made explicit the link between poverty and opportunities for populations to assert their political rights in the following statement

It is estimated that 1.3. billion people live in acute poverty today. Almost a quarter of the earth's population are unable to satisfy their basic needs... These people should have the same rights as anybody else to assert their rights, free themselves from poverty and take control of their own lives and future. .In the final analysis, development $t$ cooperation is about 
respecting the equal value of human beings and about commons security, understood not merely as the security of states but in the context of people's living conditions in the broad sense...reflected in the UN's extensive normative work. (MFA 1996/7:7).

A SIDA guidance document for country strategy affirms a democratic and rights approach to poverty reduction which affirms the Swedish intention 'to support the struggle against poverty' from the perspective of democracy, claiming that

In its broad definition, poverty is a state of the violation of almost all human rights; and lack of democracy excludes the poor and leads to greater participation in the long term (2001b: 1)

Such an approach positions the issue of poverty firmly within considerations of power (powerlessness) and agency. However, SIDA's interpretation of this perspective in practice has been to mainly focus on working with ways in which formal institutions and state political mechanisms may be strengthened to facilitate greater agency and influence from poor sectors of the population. Attention to the other side of the coin is found in those development discourses that put increasing emphasis on local participation and the self-generated activities of local groups themselves, attending to the important contribution made by civil society structures rather than a sole reliance on state channels that often fail to implement or deliver. Rocco (2000) has noted how

[i]ndividuals and groups establish a wide variety of relatively stable networks of activities that not only sustain their survival, identity and sense of worth, but which also serve as the basis for the development of practices and activities that are concerned with the direction of community and collective life, with the constitution of a 'public sphere'. (Rocco, 2000: 235)

In principle, poverty is a complex concept subject to different perceptions by stakeholders at different levels (politicians, development organizations, communities). Policies addressing poverty therefore need to be formulated through complex, multifaceted and dynamic processes which engage a wide range of actors and that address the linkages between understanding of poverty as material deprivation and as lack of agency. Because policy is an outcome of the contest between opposing forces, an essential prerequisite for a workable (social) policy is an effective voice for the poor. Friedman (2002) argues for a 'politics of informality' emerging from the terrain of informal economic and social organization.

Many authors have, however, underscored the difficulties inherent in a participation-oriented framework to poverty alleviation. Foremost among these difficulties is the issue of disjuncture between official political spaces and the lack of access to these spaces by the poor, raising the question of how genuine participation of grassroots stakeholders may be facilitated. Linguistic issues are intricately involved in the problem of participation. Different political spaces are partly defined by different linguistic practices at the same time as these linguistic practices and their meaning are the outcome of societal divisions of power. In other words, language policy cannot be seen as separate from sociopolitical struggles more generally. 
One important strategy for enhancing participation would be to take into account the multifarious uses of language and multilingualism among the poor in order to find ways of incorporating local decision-making and management of economy, health and education into formal arenas. At the same time, attention to how societal language policies exclude participation may suggest complementary remedial actions. In other words, focusing on ways in which attention to language in different spaces may reconfigure these spaces (as well as redefine new spaces) promises to facilitate the participation, mobilization and transformative agency of the poor. We shall here explicitly focus on one important space, namely education, and show the ramifications of attention to issues of multilingualism in education for many other sectors.

\section{MULTILINGUALISM AND DEMOCRACY}

How then can attention to multilingualism contribute to democratic participation, and what role does language play in 'the mobilization and sustained political action of the poor'?' (Williams 2004).

Multilingualism contributes to development of democracy at the level of the nation-state, transborder relationships, and the local community. On the regional level, multilingualism may facilitate friendly and co-operative relationships between states. In the African context, for example, millions of speakers, rather than being divided by the multitude of African languages they speak, are actually linked into regional speech communities through the existence of linguistic continua (cf. Prah, 1995) comprising languages that are spoken (albeit in different varieties) within and across borders, so-called transborder languages. These transborder languages have 'lasting advantages for national development, peaceful co-existence and international co-operation' (Chumbow, 1999: 58). Chumbow argues that national borders should be reconceptualized as meeting places, or, in his words, 'as lines of productive contact', instead of the more common situation prevailing today where 'contacts at the borderline are more often contacts of conflict rather than harmony'. In the search for ways to reinvent borders through legal instruments of cooperation, linguistic decisions are paramount.

Approaches to nation-state development need to acknowledge that fair policies on multilingualism are essential for democracy. What languages are used officially affects peoples' chances of participation in state power structures that concern them, as well their access to government agencies and services. Policies that acknowledge the importance of local languages are therefore essential in this regard. For example, Liphola (1996) reports upon how the use of vernacular languages in Mozambican elections, far from jeopardizing the flow of information, was actually essential to the success of the electoral process. In Mozambique, formulating political messages in local languages as well as Portuguese facilitated the electorate's understanding of how political views would work at the local level, as well as allowing insights on how local affairs impact on the national level.

Polices on multilingualism that grant languages and their speakers symbolic recognition are also essential for democratic development. In situations of inter-ethnic conflict, the nonrecognition of a particular language on behalf of governments may constitute 
"a rightful mobilizing factor in conflicts with multiple causes where power and resources are unevenly distributed along linguistic or ethnic lines" (SkutnabbKangas and Phillipson, 1997: 496). If language is seized upon as a symbol of ethnic mobilization, an important prerequisite in the survival of ethnic groups and the dissolution of ethnic conflicts - within and between nation states - comes to hinge on official recognition being granted to the language with a concomitant visibilization of the group as consequence. This is important because once a community is constituted symbolically, its members may come to enjoy a host of other rights and advantages that accrue to officially designated groups. A current example is South Africa, where post-apartheid struggles to accord distinct language status to a range of different varieties is part of an important historical symbolic (and material) reworking of ethnic identities that were often earlier oppressed and stigmatized. Among other reasons, this is important because other rights (for example access to historical lands) previously denied are connected to the right to and ownership of particular languages.

At the level of local community, a productive approach to issues of multilingualism and development attempts to document the ways in which individual community members use multilingual practices on an everyday basis to manage symbolic recognition and negotiate political realities with the resources at their disposal.

For example, when women street traders in Mozambique converse among themselves using a mixture of Portuguese and their own local language Ronga (so-called code-mixing), they are creating meanings and expressing stances over and above what is possible in each single language used on its own. The juxtaposition of different languages simultaneously embodies a juxtaposition of different perspectives and voices layered into each language. Attention to local multilingual practices such as these that structure social formations in the management of politics may open up new spaces for political action.

\section{MULTILINGUALISM AND ECONOMY}

English, French and Portuguese, the so-called metropolitan languages, are frequently perceived as world languages and as prerequisites for economic development. However, the African linguistic and social thinker Mazrui claims that the use of metropolitan languages, spearheaded by institutions such as the World Bank and the IMF, is part of a 'wider economic agenda intended to meet the labor requirement of foreign capital' by helping to constitute 'the creation and reproduction of this hierarchy' (1997: 44). He makes the point that instruction in Euro-languages creates and maintains 'an economy dominated primarily by foreign economic interests and, secondarily, by a small aspiring African bourgeosie' (ibid).

In fact, far from contributing to the economy, teaching foreign languages consumes valuable resources that comprise a real capital transference from poor to rich nations. The economist Francois Grin estimates that the USA saves approximately 60 billion USD a year by not teaching foreign languages, and leaving it up to foreign countries to teach their populations English. The savings are made from communication savings effect, language learning savings effects and human capital investment effects. These costs are borne by countries in the 
developing world that see metropolitan languages, English specifically, as a condition of membership to the affluent world economy, and that train their work force accordingly.

The 'destructive role' played by metropolitan languages suggests that developing economies should conserve and utilize their own linguistic resources in the functioning and management of their economies. Fishman (1991) long ago put the lie to the claim that linguistic heterogeneity in a nation is associated with lower per capita BNP. Fishman and Solano (1989) even suggest that the existence of what they term bilingualism enables many polities to attain a higher per capita income than they otherwise might.

Multilingualism is especially prevalent (and productive) in the informal sector. Outside of the formal economy, the informal sector is highly productive and plays a dynamic role in the total economy of a nation. In many developing contexts, the informal economy, involving areas such as transport, construction, and trade, may account for $50-75 \%$ or more of the work force and more than $40 \%$ of total BNP (Montiel, Agenor \& Haque, 1993). The informal sector is flexible, adaptable, and succeeds in harnessing the creative resources of collective endeavors in structures of co-operation that bridge traditional values and entrepreneurship (cf. Bruthiaux, 2002).

In general, Robinson (1996) argues that development projects need to be managed in local languages in order to allow full participation of those who are meant to benefit from these projects, stating

In terms of micro-level purposes...it is clear that development will not be owned by local people until they are able to discuss it among themselves and with outsiders without the barrier of somebody else's language. (Robinson, 1996: 260)

This is because the 'actors of change remain the people themselves' (Djite, 1993: 150).

The West African women's markets are a case in point. Women in these markets take charge of their own economic independence and engage in trading activities. It is notable that $65 \%$ of the Nigerian economy arises from the informal sector, in which the women's markets comprise a significant and growing part. When participating in the everyday workings of these markets, the women use local, regional and sometimes pidgin languages in ways that reinforce their own carefully structured market based social and welfare systems. Young women are inducted into markets via apprenticeships that include the teaching and learning of unwritten codes of conduct in local languages. Analyses reveal intricate sociopolitical mechanisms whereby multilingual language use provides a resource for economic development. The intersection of local languages and economic autonomy offers women alternatives to the male oriented formal sectors, which elsewhere frequently render women invisible, dependent and inferior.

Far from being an aberration that should be wished away, the informal sector "deserves all possible assistance in areas such as basic management training and credit" (Bruthiaux, 2002: 282). This aid should be provided in the languages used in the sector. This is also of direct advantage to the linguistic communities themselves: Bruthiaux mentions numerous examples of how the development of local economic control of grassroots projects through bookkeeping and accountancy pratices in local languages have at the same time given rise to a flourishing use of 
local languages in processes of political concientization,

Only when it is linked to specific development activities - such as borrowing in order to expand a business and gaining a degree of practical control over one's affairs can the acquisition of literacy begin to socialize participants into new and potentially life-transforming roles. (Bruthiaux, 2002: 285)

A telling example of how the development and cultivation of languages and local literacies for economic purposes bring advantages to individuals well beyond the purely material is that of women's literacy in Mozambique. In this case, when the women learnt to read and write, ostensibly to manage bookkeeping in their agricultural collective, they immediately started to employ their new skills to write letters to their husbands, migrant labourers in the South African mines. This allowed them to create a unique, gendered, female private space after having earlier been forced to rely on (male) literacy brokers, where they were subject to surveillance.

\section{MULTILINGUALISM IN HEALTH}

Education is also associated with overall, improvements in life quality, better health status and child survival, as well as nutritional status. Literacy enhances selfesteem and leads to attitude change. To obtain optimal delivery of these benefits, education is most effectively conducted in local languages.

A major health problem in many developing contexts is HIV/AIDS. How effectively information on HIV and AIDS comes across has a lot do with cross-cultural communication: authenticity of speaker, appropriateness of cultural metaphors, style of communication, the senders' standing in the community, his/her relationship with the audience etc. The West African women are again a case in point. What is obvious is that the market women not only guard their independence from men as a mechanism to ensure the future of their children and their own economic survival, but also in order to create a space in which they reveal their control over reproduction, a matter not disclosed to their husbands. Control over their lives as expressed through discourses in local languages is manifested in the highly regulated space of the market.

Material networks of the above type are also implicated in aspects of individual and group welfare relating to the consolidation of trusting social relationships, the exploration of new gender identities and the development of responsible socio-political roles and identities. Focusing on local languages open up vistas on local cultural models of care and intimacy mediated through local language resources. Giddens (1994) has stated that

[i]ndividuals who have a good understanding of their own emotional make-up and who are able to communicate effectively with others on a personal basis, are likely to be well-prepared for wider tasks of citizenship. Communication skills developed within the arenas of personal life might well be generalizable across wider social contexts. (Giddens, 1994: 119)

Local relationships of these sort carried in multilingual practices are of importance for the wider political context. 


\section{MULTILINGUALISM IN EDUCATION}

Education is a key space in considerations of language as it is the local institution most implicated in the distribution of social and cultural capital at the same time as language is the principal means whereby this distribution is accomplished and reinforced.

Schooling in developing contexts suffers a notorious medley of debilitating problems. Drop-out is high and levels of knowledge are low. Problems abound in teacher training, the implementation of appropriate teaching methodologies, and the provision of materials and textbooks. The size of classes, the lack of teachers and the scarcity of classrooms contribute to the difficulties of teaching students in languages they do not understand. Compounding all of this is that formal schooling tends to 'bracket off' learning from the social world and the cultural intertextualities of the community, and to treat learning as a commodity. Lave and Wenger (1991) suggest that problems of pedagogy in general have to do with

the ways in which the community of adults reproduces itself, with the places that newcomers can or cannot find in such communities, and with the relations that can or cannot be established between these newcomers and the cultural and political life of the community. (Lave \& Wenger, 1991: 99f)

Recent theories of language acquisition across the curriculum focus on the link between cognitive functioning and interactional and discursive formations. Learning is constituted through participation in practice and all cognitive activity is fundamentally situational, collaborative and contextualized.
Use of local linguistic resources in the form of mother tongue or bilingual education is a way of avoiding this commodification at the same time as it can facilitate community participation. Bilingual and mother tongue education is premised on the insight that children more easily acquire literacy and academic skills in the language they master best-the language of everyday socialization of the home. The use of local languages has the advantage of allowing the participation of the family and community in formal schooling in ways denied them when metropolitan languages are employed. Using languages that are intelligible to the children also permits a more appropriate interaction between pupils and teachers in the classroom and between pupils themselves, as well as the development of more socioculturally relevant methodological discourses that promise to articulate with the local curricula needs of the communities.

Despite the desirability of incorporating local linguistic resources into the classroom, multilingualism has often been seen as a problem for education. The sheer number of languages present in many multilingual contexts, the fact that students often speak a variety of language that does not conform to written standards for the languages, and logistical difficulties in incorporating these multiple varieties in traditional time-tabling formats has seemed to generate insurmountable hurdles for implementation. However, a case can be made that it is this very fluidity and multiplicity of local linguistic resources that contributes productively to children's education. This is because multilingual practices allow students to transcend and negotiate community specific values and identities associated with particular languages of learning. It also allows students to position 
themselves in a matrix of sociolinguistic meaning that offers alternative learningpersonae to those circumscribed in positions and identities found in conventional language genres. This means that students can approach topics in ways that affirm - and develop - their indigenous social identities.

The key role that multilingualism in educational spaces can play across development sectors is demonstrated in the following example. The specific example that illustrates how multilingualism and acknowledgement of local linguistic resources contribute to and serve as a bridge between democracy, economy, education and health is that of a German aid project in Ghana (Kurt Komarek, personal communication). At the level of nationstate Ghana recognizes the legitimacy of its many languages as formulated in the national language policy. However, this policy is not implemented in practice. Because of this, the German aid programs are community based local grassroots attempts to provide the language educational services not acknowledged by the government itself. Even though the programs were initially built for educational purposes, they have nevertheless become powerful means for communities to expand the parameters of democracy and to promote new forms of local participation and political inclusion. For example, through materials produced in mother tongues for the wider community, but generated in conjunction with the production of school materials, adults now have access to discursive spaces where they can negotiate and deal with global, national and political issues of major concern, such as general elections and AIDS. In other words, providing education in indigenous languages is at the same time helping to create a site where the local community can strategically respond to the situated impact of globalization and national politics, a 'site of mediation' (Alvarez el al., 1998). The fact that local languages give access (albeit limited) to global and national discourses, lends support to teaching them. However, it is noteworthy that these developments have only been made possible through the creation of a broad coalition of political alliances outside of the sphere of the State, in the form of powerful local publishing houses, distributors, authors and financiers such as Lufthansa and Nestle. This broad alliance has created jobs and economic gains through the language industry (and the real infusion of capital value into the local language) developed around the production, distribution and consumption of language materials, that simultaneously serves to enhance the visibility and linguistic identities of the speakers.

Community based schooling in local languages thereby contributes to both a representation of community identity on community terms, as well as linking language issues to issues of economy and redistribution. In Ghana, speakers are inserting local languages into the dominant political landscape, creating a sense of space where communities can negotiate political visibility and formulate new demands for justice and redistribution: the community is its own agent, and the political discourse it formulates with demands for new inclusive forms of citizenship are carried in language political activities and strategies of opposition and resistance that contest the rights of governments to ignore their own policies. 


\section{SUMMARY}

Language is at the nexus of poverty. Language is a social and political concept that is firmly locked into discourses of welfare, justice, and equity Multilingual practices are integral to the management of material and economic capital and contribute to the development and nurturing of political consciousness, social identities and literacy skills. The use of local linguistic resources increases participation within and between local communities and encourages articulation of concerns and ideas on trajectories of development across a broad segment of the community, whose voices have traditionally not been heard. In other words, issues of language are essential to the symbolic recognition, material and physical welfare and political participation of the poor.

From a remedial perspective, language, specifically multilingualism, is a local resource that needs to be carefully mined and exactly deployed. Our emphasis on the role of informal networks and economies suggests that remedies need to address (a) the possible tension between solutions directed at the formal, official, arenas of society and grassroots interests, and (b) the desirability of finding ways of supporting and consolidating the practices of multilingual language use found in informal contexts.

\section{REFERENCES}

Alvarez, S.E., Dagnino, E. and Escobar, A. (eds.) (1998) Cultures of Politics - Politics of Culture: Revisioning Latin American Social Movements. Boulder, CO: Westview Press.

Bruthiaux, P. (2002) Hold your courses: Language education, language choice and economic development. TESOL Quarterly, 36 (3): 275-296.
Chumbow, B. (1999) Thematic glossaries in language development. In B. Smeija (ed.) Maintaining Contact through Language. Berlin: John Benjamin.

Djite, P. G. (1993) Language and development in Africa. International Journal of the Sociology of Language 100 (101): 149-16.

Fishman, J. (1991) An interpolity persepctive on the relationship between linguistic heterogeneity, civil strife and per capita gross national product. International Journal of Applied Linguistics, 1: 5-18.

Fishman, J. and Solano, F.R. (1989) Crosspolity linguistic homogeneity and per capita gross national product: An empirical exploration. Language Problems and Language Planning 13: 103-18.

Fraser, Nancy. (1995). From redistribution tom recognition? Dilemmas of justice in a 'postsocialist' age. New Left Review 212 (July/August), 68-91.

Friedman, S. (2002) Equity in the age of informality: labour markets and redistributive politics in South Africa. Working Papers Series 160: Brighton, IDS.

Gadamer, Hans-Georg. (1960). Truth and Method. New York: Continuum Press.

Giddens, A. (1994) Beyond left and right. The future of radical politics. Cambridge: Polity Press.

Lave, J. and Wenger, E. (1991) Situated Learning. Legitimate Peripheral Participation. Cambridge: Cambridge University Press.

Liphola, M. (1996) The use of Mozambican languages in the elections. In B. Mazula (ed.) Mozambique: Elections, Democracy and Development. Maputo: Inter-Africa Group.

Malpas, Jeff. (nd). 'Language is conversation'. On Gadamer, Language and Philosophy. (ms)

Markee, N. (2002) Language in development. Special issue of TESOL Quartely, 36(3).

Mazrui, A. (1997) The World Bank, the language question and the future of African education. Race E Class 38(3): 35-48.

Montiel, P.J, Agenor, P-R., and Hague, N. (1993) Informal Financial Markets in 
Developing Countries. A Macro-economic Analysis. Oxford: Blackwell Prah,

K. K. (1995) African languages for the mass education of Africans. Bonn: German Foundation for International Development, Education, Sciences and Documentation Centre.

Robinson, C.D.W. (1996) Language Use in Rural Development: An African Perspective. Berlin: Mouton de Gruyter.

Rocco, R. (2000. Associational rights-claims, civil society and place. In E. I. Isin (ed.) Democracy, Citizenship and the Global City. London and New York: Routledge (pp. 218-240).

Sen, A. (1999). Development as Freedom. New York: Oxford University Press.

Skutnabb-Kangas, T. and Phillipson, R.

(1997) Linguistic Human Rights and development. In C.J. Hamelink (ed.) Ethics and Development. On Making Moral Choices in Development Cooperation. Amsterdam: Kok Kampen (pp. 56-69).

Stroud, Christopher. (2001). African Mother tongue programmes and the politics of language: Linguistic Citizenship versus Linguistic Human Rights. Journal of Multilingual and Multicultural Development, 22(4): 339- 356.

Stroud, C. (2002) Towards a policy for bilingual education in developing countries. Stockholm: SIDA. New Education Division Documents 10.

Williams, G. (2004). Evaluating participatory development: Tyranny, power and (re) politicization. Third World Quarterly 25/3:557-78. 